\title{
Far-Right Extremism: Is it Legitimate Freedom of Expression, Hate Crime or Terrorism?
}

\author{
Dr David Lowe \\ Senior Research Fellow, Leeds Beckett University Law School \\ Email: D.Lowe@leedsbeckett.ac.uk \\ Phone number: 07528192637 \\ Website: drdavidlowe.co.uk
}




\section{Introduction}

Following the far-right inspired attack on two mosques in Christchurch, March 2019, social media and electronic communication companies were heavily criticised by politicians for not removing from their sites extremist content that inspires individuals to carry out violence, especially in relation to far-right extremism. ${ }^{1}$ Politicians' criticism existed prior to the Christchurch attack, for example UK politicians claimed social media sites were failing in relation to dealing with extremism, adding that they should take greater responsibility. ${ }^{2}$ Important to social media and electronic communications companies is the ability to differentiate between legitimate political and religious content protected under the parameters under the right to freedom of expression and what is legally defined as extremist material that glorifies, promotes or incites hatred or violence. These companies are not the guardians of the right to freedom of expression; that is the role of legislators (who invariably are politicians) and the judiciary. It is important that state legislators begin to address this in earnest. Dave Thompson, the chief constable of the UK's West Midlands Police, recently stated that farright extremists are growing in number and are more intent on committing terrorist attacks. In relation to how far-right extremists are using various communications, he added they are not using them to promote their ideology, '... it is a much-fixated approach to attacking people.'

This is a doctrinal legal study covering the right to freedom of expression, hate crime and the proscription of extreme far-right groups as terrorist organizations. This article differentiates between the far-right and extreme far-right, where extreme far-right are neoNazi groups that are anti-Semitic, homophobic, racist, advocating white supremacy and violent overthrow of liberal democracies, while far-right groups are generally antiimmigration, anti-Islam and in Europe, anti-EU. Not being bilingual and simply due to the fact their legislation, case reports and policy documents are in English, the focus is mainly on Australia, Canada, New Zealand, the UK and the US jurisdictions. In the examination of 
these legal issues the disparity between these states jurisdictions' protection of the freedom of expression, legislating for hate crime and proscription of groups as terrorist organizations is analysed, revealing a conundrum for social media and electronic communications companies in deciding if speech is legitimate political or religious content, or is extremist content that should be removed from their sites. The article concludes with a recommendation of how this disparity between these states can be removed by introducing a minimum standard legal provision providing adequacy in relation to what expression/speech is protected under the right to freedom of expression, comparable legislation related to hate crime and proscription of terrorist organizations.

\section{Social Media and Moderating Extremist Content}

This section is a brief overview and contextualisation of social media companies process of moderating content that violates their policy and rules on hate speech. The unprecedented influence granted by social media has become central as to how terrorist organisations promote and execute their cause, granting terrorists and extremists a greater ability to disseminate their propaganda to targeted audiences. ${ }^{4}$ This includes attempts to radicalize, recruit and train remote groups and individuals through social media ranging from publishing regular motivational reports of terror groups' successes to using high quality images and online clips showing brutal violence and evocative imagery, accompanied by high production values and music. ${ }^{5}$ To put into context how great extremists and terrorists' reach can be, in 2017 active users on Facebook was estimated at 2 billion, YouTube at 1.5 billion and Twitter, 328 million. ${ }^{6}$ Having such a wide reach enabled Islamic State (IS) to recruit over 30,000 foreign fighters from sixty-five countries and radicalize individuals to carry out 'lone wolf' attacks by providing instruction on topics ranging from preparing improvised explosive devices to guidelines on how to carry out effective vehicle and knife attacks. $^{7}$ 
Social media companies content moderation processes are broken down into three stages, creation, enforcement and response where creation is the development of the rules (the terms and conditions on users), enforcement is the flagging of problematic content is where rules are breached and response is the internal appeals process. ${ }^{8}$ The enforcement stage raises concerns that private, social media companies are regulating the exercise of freedom of expression, an area that critics have called censorship. ${ }^{9}$ In the enforcement stage most human rights violations by the companies are likely to occur as the limitations of expression applied by these companies reflect the biases experienced by predominantly white and male staffers (and that includes the programmers who create algorithms). ${ }^{10}$ Most of the social media companies have responded to the growth of extremism by pledging to work together to identify and remove extremist content by using a shared database. ${ }^{11}$ One problem with this database is that algorithms modelled on Islamist jihadism may not catch material from other extremists groups such as the far-right and extreme far-right. ${ }^{12}$ It is submitted with Al Qaeda and IS having been designated globally as international terrorist groups, it makes it easier for social media companies to recognise and remove content related to their extremist ideology. An example of this is how Twitter repeatedly removed IS users.

Twitter was the most accessed form of social media IS used. The former Director of the EU's policing agency, Europol, claimed that IS had up to 50,000 different Twitter accounts, tweeting up to 100,000 messages a day. ${ }^{13}$ Berger and Morgan claim the number of IS Twitter accounts was as high as $90,000,{ }^{14}$ thereby doubling the number of IS' daily tweets. Katz highlights the difficulty intelligence and policing agencies face in monitoring social media and encrypted electronic communications. Using the example of Twitter, IS regularly circumvented the blocking of their social media accounts. ${ }^{15}$ One method being with IS account holders having multiple back-up accounts. they would tweet followers to follow and retweet up to six accounts at a time. Another method was IS by-passing countries like Syria 
who shut down internet and phone communications under their control by using satellite modems to create hotspots and temporary pop-up wi-fi networks. ${ }^{16}$ Twitter alone became a launch pad for IS recruitment or calls for lone wolf attacks or to send dangerous messages into every corner of the world. ${ }^{17}$ Twitter continued to close down IS linked accounts and as the policing of other social media platforms like Facebook and YouTube were becoming more aggressive, IS moved to more heavily encrypted communications platforms like WhatsApp and, the preferred platform for most extremist groups, Telegram. ${ }^{18}$ This is because Telegram is a free, cross-platform messaging app offering secure messaging allowing users to use a 'self-destruct option', where messages can be deleted as soon as they are viewed by the recipient. ${ }^{19}$ In relation to far-right extremists, due to the diversity among most states as what is protected under the freedom of expression, hate crime and proscribing/designating extreme far-right groups as terrorist organisations, the task social media companies face in determining whether content on these groups' sites should be removed is not as straight forward as that when dealing with international Islamist terrorist groups like IS and Al Qaeda.

\section{Right to Freedom of Expression}

In a liberal democracy the right to freedom of expression is a vital human right that differentiates it from an authoritarian regime and most liberal democracies have some form of legislative provision protecting that right from being incrementally eroded by the state. This can come in the form of being enshrined in a state's written constitution, a bill of rights, a convention, a charter or through a statute allowing the judiciary to assess if an executive government's legislation is compatible with human rights provisions. Examples includes the Council of Europe's European Convention on Human Rights (ECHR), followed by virtually all European states, the US' Bill of Rights, which are amendments to the US constitution and 
Canada's Charter of Rights that is entrenched in the Canadian constitution, both protecting individuals' rights. All these measures include the right to freedom of expression.

Article10(1) ECHR provides everyone the right to freedom of expression, including freedom to hold opinions and to receive and impart information and ideas without interference by a public authority, regardless of frontiers. This is a qualified right allowing state agencies to interfere with this right only when it is in accordance with the law and necessary in a democratic society when it is in the interests of:

1. national security;

2. territorial integrity or public safety;

3. for the protection of the reputation or rights of others;

4. for maintaining the authority and impartiality of the judiciary;

5. for the prevention of disorder or crime, for the protection of health or morals; or,

6. for the protection of the rights and freedoms of others. ${ }^{20}$

The first amendment of the US Bill of Rights protects freedom of expression stating that Congress shall make no law that abridges the freedom of speech, or that of the press. Under section 2(b) Canadian Charter of Rights \& Freedoms everyone has the right to freedom of thought, belief, opinion and expression, including freedom of the press and other media of communication. Again, this is a qualified right as section 1 of the Charter states the right is guaranteed only to such reasonable limits prescribed by law and can be demonstrably justified in a free and democratic society. New Zealand's freedom of expression is protected in the Bill of Rights Act 1990 allowing everyone the right to freedom of expression, including the freedom to seek, receive and impart information and opinions of any kind in any form. ${ }^{21}$ The Australian Constitution does not expressly protect the freedom of expression. Although Australia is a signatory to the International Covenant on Civil and Political Rights, a multilateral treaty adopted by the United Nations General Assembly, there has been no express implementation of its principles, which includes the right to hold opinions without 
interference and the right to freedom of expression. ${ }^{22}$ As such, freedom of expression and other human rights provisions come under the protection of judge made common law.

Judicial Interpretation of Right to Freedom of Expression

To put some context into what is legally acceptable in relation to freedom of expression, in the UK case Redmond-Bate v Director of Public Prosecutions ${ }^{23}$ Lord Justice Sedley said:

'Freedom of speech includes not only the inoffensive but the irritating, the contentious, the eccentric, the heretical, the unwelcome and the provocative, provided it does not tend to provoke violence. Freedom only to speak inoffensively is not worth having. [My emphasis $]^{24}$

Important in this decision is that freedom of speech does not provoke violence and the European Court of Human Rights (ECtHR) adopted a similar approach. ${ }^{25}$ In Erbaken v Turkey the ECtHR tempered freedom of expression saying that tolerance and respect for the equal dignity of all human beings constitutes the foundation of a democratic, pluralistic society, adding:

'That being so, as a matter of principle it may be considered necessary in certain democratic societies to sanction or even prevent all forms of expression which spread, incite, promote or justify hatred based on intolerance ... ${ }^{26}$

Similar judicial interpretations of the right to freedom of expression can be found globally. In $R v$ Andrews $^{27}$ the Canadian Supreme Court Justice of Appeal Corey stated the Charter of Rights must serve to protect the expression of new and different ideas no matter how upsetting those ideas may be to identifiable groups. He added freedom of thought is of limited value without the freedom to express that thought, to advocate the adoption of a new concept or the termination of an institution that has become outmoded or unfair. Justice Corey stated that certain limitations are important to this right, especially in enabling 
Canadians who are members of identifiable groups to carry on their lives without being victimized by the deliberate, vicious promotion of hatred against them. On this point he recognised the necessity of a strong presumption against limiting the freedom of expression, modest restraints on expressive activity in order to suppress hate propaganda were seen to be necessary and justifiable in the multi-cultured nation of Canada.

In Texas $v$ Johnson ${ }^{28}$ the US Supreme Court examined if burning the US flag breached the first amendment right of freedom of expression. The Court held that freedom of expression guarantees freedom to be intellectually diverse or even contrary and the right to differ as to things that touch the heart of the existing order, adding that encompassing the freedom to express publicly one's opinions about the US flag, included opinions that are defiant or contemptuous. The US Supreme Court has delivered decisions where the first amendment protection of freedom of expression does not apply. These includes defamation which is not protected where malicious, scandalous and defamatory statements are published and malice may be inferred in the publication of the statement. ${ }^{29}$ Another category is insulting or fighting words as they do not contribute to the expression of ideas nor do they possess social value in the search for truth. The court saw such terms as those which by their very utterance inflict injury or tend to incite an immediate breach of the peace. ${ }^{30}$ Sedition is not protected where statements are made preparing revolution to overthrow and destroy the US government by force and violence. ${ }^{31}$ In Brandenburg the US Supreme Court laid down tighter parameters as to when seditious statements are not protected, holding that inflammatory speech is protected unless such speech is directed to inciting or producing imminent lawless action and is likely to incite or produce such action. ${ }^{32}$

The judiciary in all these jurisdictions allow offensive, heretical, extremist views under the legal protection of freedom of expression. It is only when these views promote violence, incite lawless action or promotes or justifies hatred based on intolerance are those 
boundaries crossed and no longer protected under this right. For social media and electronic communications companies, this apparent commonality between states as to what is acceptable as freedom of expression should be a sufficient barometer in assessing what is and is not acceptable under this right in their self-regulating processes. However, a problem for these companies is how hate crime differs between these states regarding the type of expression amounting to a hate crime, with some not having any legal provisions related to hate crime. For these companies this causes confusion, resulting in obfuscation.

\section{When Right Wing Narratives and Statements go From Being Offensive to Hate Crime}

It is important to ascertain when comments cross the parameters of what is acceptable under the right to freedom of expression and becomes a criminal offence where there should be sanction or prosecution by the state. As far-right and extreme far-right groups become internationalised, it is important that states have a consistent and comparable level of legislation related to hate crime, similar as they did in relation to dealing with the Islamist inspired terrorist groups. ${ }^{33}$ Comments that amount to hate crime will cross the parameters of what is acceptable under the right to freedom of expression, however how states apply their laws related to hate crime varies considerably. In relation to the far-right and extreme farright, the lack of global level consistency can be problematic for social media companies' moderation processes.

\section{Hate Crime: Canada}

In Canada racial hatred offences are contained in the Canadian Criminal Code where it is an offence other than in private conversation, to communicate statements that wilfully promotes hatred to an identifiable group. ${ }^{34}$ In relation to other criminal offences the Canadian Criminal Code allows where an offence is motivated by bias, prejudice or hate based on race, national or ethnic origin, colour, religion, sex, age, mental or physical disability, sexual 
orientation or any similar factor to be taken into consideration as an aggravating sentencing factor. ${ }^{35}$ In relation to hate crime per se, section 319 of the Criminal Code looks to be effective against an individual, but is not strict or effective enough to deal with extremist group activity. As such Liberal MP, Irqa Khalid's private members motion, M-103 calling on Canada's government to condemn Islamophobia and all forms of systematic racism and religious discrimination was passed by 291 to 91 votes in an attempt to target far-right activity and quell the climate of hate and fear. ${ }^{36}$ Although it is a non-binding motion, it requires the Canadian government to collect data on hate crime, conduct official assessments of affected communities. Motion M-103 is still causing consternation on two counts. One being how to legally define the term Islamophobia and secondly that the motion would limit free speech in Canada as well as by singling out Islam for special treatment could cause further resentment by non-Muslims. ${ }^{37}$ To assess the scale of hate crime in Canada, in 2018 1,798 hate crimes were recorded by the police, of which 742 were racist/xenophobic, 341 were anti-Semitic, 165 were bias against Muslims, 116 were bias against members of other religions and 170 were bias against sexual orientation. ${ }^{38}$

There have been several successful prosecutions under Canada's hate crime laws that covers a wide range of hate crime activity. In $R v$ Bissonette,${ }^{39}$ Bissonette was convicted of six counts of first-degree murder and six counts of attempted murder after he entered a Quebec mosque with an automatic rifle and a pistol. The Court found Bissonette's crime was motivated by his bias, prejudice and hate with regards to Muslims. In $R v$ Andrews, ${ }^{40}$ Andrews was the leader of the Nationalist Party of Canada and was convicted for the wilful promotion of hatred against an identifiable group in the publication of the Party's paper, the Nationalist Reporter in promoting white supremacy. In $R v$ Keegstra,${ }^{41}$ Keegstra was a high school teacher who communicated anti-Semitic statements to his students. He was convicted 
of wilfully promoting hatred against an identifiable group. He did appeal, but the Canadian Supreme Court found Keegstra's infringement of the Criminal Code was justified. ${ }^{42}$ Hate Crime: UK

In the UK hate crime comes under Part III of the Public Order Act 1986, creating the offences of using threatening, abusive or insulting words or behaviour or displays written material which is threatening, abusive or insulting with the intent of stirring up racial hatred or having regards to the circumstances racial hatred is likely to be stirred up ${ }^{43}$ and publishing or distributing such material. ${ }^{44}$ Racial hatred is defined as , '...hatred against a group of persons defined by reference to colour, race, nationality (including citizenship) or ethnic or national origins'. ${ }^{45}$ Part $3 \mathrm{~A}$ of the Act introduced offences based on the grounds of religious hatred and hatred on the ground of sexual orientation. Under the Act religious hatred means hatred by reference to religious belief or absence of religious belief, ${ }^{46}$ with hatred on the grounds of sexual orientation meaning hatred by reference to sexual orientation be it towards persons of the same sex, the opposite sex or both. ${ }^{47}$ In 2018/19 103,319 hate crimes were recorded by the police in England and Wales with 78,991 for race hate crime, 8,566 for religious hate crime, 14,491 for sexual orientation hate crime, 2,333 for transgender hate crime and 18, 256 for disability hate crime, with half of those offences being public order offences and a third for violence against the person. ${ }^{48}$ This does seem a lot higher than Canada's figures and can be explained that in addition to the UK having a larger population (66 million) compared to Canada (37 million), there will be differences in reporting practice between the UK and Canadian police.

In 2018-19 there were 10,817 convictions for hate crime with the sentences delivered ranging from custodial prison sentences to fines. ${ }^{49}$ A number of these hate crimes have targeted UK politicians. An example was John Nimmo's conviction in relation to tweets he 
sent to Jewish MP Luciana Berger. Shortly after the murder of MP Jo Cox by Thomas Mair in June 2016 that was inspired by the extreme far-right narrative, Nimmo, who admitted being a Nazi, was convicted for making anti-Semitic death threats to Luciana Berger. One of the tweets Nimmo sent to the MP said, 'watch your back Jewish scum regards your friend the Nazi'. The tweet that caused Berger to fear for her own safety was sent three weeks after Cox's murder saying she would, 'get it like Jo Cox'. While there was no physical assault, this type of Internet trolling can cause great anxiety in the recipient and Nimmo was convicted of sending malicious communications, which due to the anti-Semitic nature of the correspondence, was classified as hate crime $\mathrm{e}^{50}$ and he received a 27 month custodial sentence. $^{51}$

\section{Hate Crime: US}

Following the assassination of Martin Luther King in 1968, the US government introduced the Civil Rights Act $1968^{52}$ creating the federal crime of wilfully injuring, intimidating or interfering with, or attempts to injure, intimidate or interfere with any person because of his race, colour, religion or national origin. The Hate Crimes Prevention Act $2009^{53}$ introduced during the Obama presidency expanded the 1968 Act to apply to crimes motivated by a victim's actual or perceived gender, sexual orientation, gender identity, or disability, and dropped the prerequisite that the victim be engaging in a federally protected activity. Under section 249 of the Act it is an offence to cause or attempt to cause bodily injury to a person because of that person's race, colour, religion or national origin ${ }^{54}$ or because of their gender, sexual orientation, gender identity or disability. ${ }^{55}$ However, bodily injury does not include emotional or psychological harm to the victim. ${ }^{56}$

Examples of convictions under the Act include US v Paul Beebe et.al ${ }^{57}$ where the three defendants wilfully caused bodily injury on a disabled young adult Navajo man. A self- 
proclaimed white supremacist, Beebe's apartment was adorned with Nazi swastikas and other Nazi paraphernalia. The defendants shaved a swastika into the hair at the back of the victim's head, writing 'KKK' and 'White Power' in the lines of the shaved swastika. The defendants heated wire hangers and seared a swastika in the victim's right bicep. The defendants argued that section 249(1) was unconstitutional and the federal government exceeded their powers in legislating under the thirteenth amendment that states neither slavery nor involuntary servitude, except as a punishment for crime whereof the party shall have been duly convicted, shall exist within the United States, or any place subject to their jurisdiction. The US District Court for the District of New Mexico followed the US Supreme Court decision in USv Flore $^{58}$ that upheld the constitutionality of section 249 (1) under the thirteenth amendment. In US v Frankie Maybee, ${ }^{59}$ Maybee was charged with five counts of committing federal hate crime under section 249(1). With his co-defendant, Maybee conspired to cause bodily injury to five Hispanic males because of their national origin. Maybee chased the males in his truck, repeatedly striking the Hispanic Males' car causing it to crash and burst into flames, injuring the five men. Maybee used the argument that under the thirteenth amendment section 249(1) was unconstitutional. Once again, this argument was dismissed by the US District Court Western District of Arkansas. In 2017 Joshua Vallum was the first person convicted under section 249(2) of the Act for targeting a transgender victim. He received a 49-year prison sentence for murdering a 17-year-old transgender woman he dated and later killed on finding out she was transgender. The conviction led to the US Attorney General saying, 'The Justice Department will continue its efforts to vindicate rights of those individuals who are affected by bias motivated crimes. ${ }^{60}$

Hate Crime: Australia and New Zealand

In Australia the right to freedom of expression seems to be fettering the development of hate crime. Added to Australia's Racial Discrimination Act 1975 through the Race Hate 
Crime Act 1995, section 18C appears to be relatively ineffective to deal with the increase in hate crime activity. This has been an issue for many years and has raised the debate in Australia leading the current Australian government to consider overhauling section $18 \mathrm{C} .{ }^{61}$ Under section $18 \mathrm{C}$ it is unlawful to otherwise than in private, to do an act where it is reasonably likely to offend, insult, humiliate a person or a group of people where the act is done because of race, colour, or national or ethnic origin of that person or some or all of the group of people. Only a small amount of cases has made their way into the court system. ${ }^{62}$ One problem Australian victims have is hate speech is a civil wrong not a criminal offence. This means individuals initiate complaints in the courts not state agencies. As a result, most complaints do not proceed any further than lodgement or are resolved by conciliation, with many complaints being withdrawn or abandoned. ${ }^{63}$ With rights and freedoms being common law rights, the Australian legislature does not want to be seen as restricting those rights. That said, there have been a few successful complaints under section 18C. In Kanapathy $v$ In de Braekt $^{64}$ Kanapathy was a security guard at the Central Criminal Courts in Perth where a lawyer, de Braekt, racially abused Kanapathy after refusing a security check by calling him a 'Singaporean Prick' and repeatedly swore at him. De Braekt was ordered to pay Kanapathy AUS\$ 12,500 and was struck off. In Ejueyitsi v Commissioner of Police (Western Australia) ${ }^{65}$ Ejueyitsi was humiliated by a police officer in a public place by unlawfully handcuffing him and stripping his clothes off while saying to Ejueyitsi, 'I am going to deal with you, you bloody African'. The complaint was upheld by the Federal Magistrates Court. Successful complaints have been all too rare an occurrence and it is time the Australian legislature considers introducing hate crime offences that have a minimal impact on the freedom of expression.

The Australian state of Victoria attempted to do this by introducing the Racial and Religious Tolerance Act 2001 creating unlawful racial ${ }^{66}$ and religious vilification. ${ }^{67}$ Under 
sections 7 and 8 respectively, the Act makes it unlawful on either grounds of race or religious belief of another person or class of persons, for a person's conduct to include hatred against, serious contempt for or revulsion or serious ridicule of that other person or class of persons. The Act defines race as including colour, descent or ancestry, nationality or national origin or ethnicity or ethnic origin with religion defined as holding or not holding a lawful religious belief or view. ${ }^{68}$ Since records began in 1994 only 21 people have been convicted under hate crime laws in Australia, despite state police forces recording thousands of offences connected to discrimination and in the nineteen years since the Racial and Religious Tolerance Act 2001 commenced only three people have been convicted under the Act. ${ }^{69}$ The three convictions are from the one case where three men, including the former leader of the far-right group United Patriots Front, Blair Cottrell, were found guilty of religious vilification in 2017. Protesting against the building of a mosque in Bendigo in central Victoria, the three men staged a mock beheading and were found guilty of religious vilification. The men only received a 2,000 Australian Dollar fine each from Melbourne Magistrates Court. ${ }^{70}$ Not only is there a disparity in how hate crimes are legislated, commenced and investigated in Australia, Canada, the UK and the US, there is also disparity in sentences delivered by the courts between these states.

Perhaps the biggest disparity between states' hate crime is New Zealand that has no hate crime legislation. The closest is under the Human Rights Act $1993 .{ }^{71}$ Under this Act, racial harassment is unlawful where a person uses language (written or spoken), or visual material or physical behaviour that expresses hostility against, or brings into contempt or ridicule any person on the ground of their colour, race or ethnic origin. ${ }^{72}$ It is worth noting this provision is not an offence, merely an unlawful activity and explains why racial harassment complaints are made solely to the NZ Human Rights Commission, not the police. New Zealand's racial harassment does not cover serious threats to racial harmony because the right to freedom of 
expression under the Bill of Rights 1990 enables people to make highly controversial or unpopular remarks. ${ }^{73}$

In 2017 New Zealand government ministers saw no need for a specific hate crime offence because such offences were rare. At that time the police commissioner said reports of a rise in hate crime were anecdotal, saying it was difficult to measure as the police did not keep records of hate crime. ${ }^{74}$ The 2019 New Zealand Crime and Victims Survey found that $4 \%$ of the 8,000 respondents were in the highly victimised category (320 of total respondents) with this group being predominantly Maori or people not in a legally recognised relationship (that is members of the LGBT community). ${ }^{75}$ In response to the 2019 Christchurch attack, the data from the survey strongly recommends that New Zealand government ministers reappraise the need for hate crime legislation. In April 2019 New Zealand's Justice Minister Andrew Little stated he was considering fast-tracking a law review that could see race hate crimes made a legal offence, ${ }^{76}$ however, twelve months after the attack no such legislation has been introduced.

\section{The Disparity Between Nation States' Hate Crime Law}

While it appears that all the states in this study have comparable law in relation to what is protected under freedom of expression, there is a great disparity in how they deal with expression and speech that amounts to a hate crime. There is also disparity in how the states deal with hate crime. As discussed above, Australia treats it as civil litigation not a crime and New Zealand has no legislation covering hate crime. While Canada and the UK are very proactive in enforcing their hate crime law, there are differences between these two states and the US, one example of which is the practice of cross burning in the US.

While it is laudable and a positive step that US hate crime legislation has resulted in convictions, it is questionable if the US justice department is truly continuing its efforts to 
protect individuals affected by bias motivated crime due to section 249 Hate Crimes Prevention Act relating solely to bodily injury and not emotional or psychological harm to a victim. Cross burning has been questioned in US courts if such practice amounts to hate speech under the first amendment. Cross burning is a form of expression associated with hatred and prejudice towards the US' African-American community. Cross burning originated at the end of the US 1861-1865 Civil War when Confederate guerrilla groups and the Ku Klux Klan (KKK) used it as a symbol of racial supremacy to terrorise newly freed black slaves. It was used by the KKK throughout the 1920's when the lynching of black people was commonplace. ${ }^{77}$ Particularly in US southern states, cross burning is used as a warning and a threat to any person seeking to improve the political or economic condition of black persons. ${ }^{78}$ There is no doubt this practice is designed to cause harassment, alarm and distress towards the intended victim, or in the words of section 249(c)(1), would cause emotional or psychological harm in that victim. As such, cross burning should be treated as a hate crime, but paradoxically this practice is seen as an expression protected under the first amendment.

Even though some US states and provinces tried to legislate against cross burning, the legislation was held as unconstitutional (and consequently unlawful) by the US Supreme Court. In R.A.V. v City of St. Paul ${ }^{79}$ the defendant burned a cross in the fenced yard of a black family who lived across the street where the defendant was living. Convicted of disorderly conduct under an ordinance issued by the City of St. Paul, the defendant claimed the ordinance was unconstitutional under the first amendment and the cross burning was merely an expression. The Supreme Court held the ordinance was unconstitutional under the first amendment because it singled out display of swastikas and cross burning that amounted to a right-wing expression of hatred. Also, the Court saw a problem with the ordinance as it punished persons who knew their actions would amount to alarm or resentment and, as the 
defendant did not utter a threat or incite violence, the defendant's actions came under the protection of expression under the first amendment.

In Virginia $v$ Black $^{80}$ the case contained two separate occurrences of cross burning. The first was Barry Black, who was Virginia's KKK leader. He burned a cross at a KKK rally in a field on private property belonging to a person sympathetic to the KKK. The second occurrence was Elliott and O’Mara who burned a cross on a black neighbour's property because the neighbour made complaints to Elliott' mother about the two of them shooting guns for target practice in their back yard. Both were convicted under a Virginia state law of burning crosses with the intent to intimidate a person or group of persons, where under the statute, cross burning is prima facie evidence of intent to intimidate a person or group of persons. In relation to Black, the Court disapproved of the section that burning a cross is prima facie evidence of intent, stating that cross burning may mean a person is engaging in constitutionally prescribable intimidation, but it is also seen as core political speech under the first amendment. As such, the US Supreme Court found in Black's favour. Regarding Elliott and O'Mara, the Court held it must be proved in burning the crosses the defendants intended to intimidate people, adding if the section that cross burning was prima facie evidence of intent, then the Virginia law would be unconstitutional. The Supreme Court returned the case to the Virginia State Court for the retrial of the two men regarding the issue of proving intent. If these were UK cases all the defendants would have been convicted of hate crime.

The UK's the Anti-Terrorism, Crime and Security Act 2001 amended the Crime and Disorder Act 1998 by introducing racially or religiously aggravated offences. This includes assault ${ }^{81}$ and criminal damage, ${ }^{82}$ but importantly, it also includes public order and harassment offences. In relation to public order offences it includes racial or religious aggravated disorderly behaviour. ${ }^{83}$ In relation to this offence the offender only has to use threatening words or behaviour or disorderly behaviour within the hearing or sight of the victim causing 
harassment, alarm or distress and it may be committed in public or private. ${ }^{84} \mathrm{In}$ relation to harassment it covers the offences of harassment and stalking causing alarm or distress ${ }^{85}$ and putting a person in fear of violence where the stalking involves fear of violence or serious alarm or distress. ${ }^{86}$ In both of these offences no physical assault or to use the words of section 249 of the US' Hate Crime Prevention Act 2009, no bodily injury is required, only the equivalent of emotional or psychological harm has to be proved under the UK legislation which is alarm, harassment or distress. In the rest of Europe, for those states signed up to the ECHR, cross burning would certainly be outside the protection of the right to freedom of expression as this practice would be seen as a form of expression that spreads, incites, promotes or justifies hatred based on intolerance ${ }^{87}$ and therefore would amount to a hate crime. Likewise, in Canada the US practice of cross burning would amount to a hate crime simply because the connotations behind this activity would be recognised as the wilful promotion of hatred against an identifiable group. In Australia and New Zealand this would not be a crime, except potentially in the Australian state of Victoria.

\section{The Disparity between States in Proscribing Extreme Far-Right Groups as Terrorist Organisations}

In December 2016 the UK was the first western state to proscribe extreme far-right neo-Nazi groups as terrorist organisations, initially with the group National Action. ${ }^{88}$ The groups Scottish Dawn and NS131, which morphed out of National Action, have also been proscribed because their views were seen as exceeding the acceptable parameters of freedom of expression by glorifying and promoting violence. In February 2020 two further extreme far-right groups were proscribed, System Resistance Network (which is spin-off from National Action) and Sonnenkreig Division (that is linked to the US group Atomwaffen). ${ }^{89}$ Under section 3 Terrorism Act 2000 the Home Secretary has the authority to proscribe groups as terrorist organisations if that group is concerned in terrorism. ${ }^{90}$ Being concerned in terrorism includes if the group: 
(a) commits or participates in acts of terrorism;

(b) prepares for terrorism;

(c) promotes or encourages terrorism; or

(d) is otherwise concerned in terrorism. ${ }^{91}$

Promoting or encouraging terrorism includes the glorification of the commission or preparation of terrorist acts. ${ }^{92}$ For glorification of conduct it is unlawful if persons who become aware of a group's glorification of terrorist acts is conduct that they should emulate. ${ }^{93}$ Under the Terrorism Act 2000 the term 'glorification' includes any form of praise or celebration. ${ }^{94}$ In determining actions that amount to acts of terrorism, underpinning this is the UK's legal definition of terrorism, which in essence requires the use or threat of action designed to influence a government or an international governmental organisation or to intimidate the public or a section of the public where the action is for the purpose of advancing a political, religious, racial or ideological cause. ${ }^{95}$ The action must:

1. Involve serious violence against a person; or

2. Involve serious damage; or

3. Endangers a person's life (other than the person committing the action); or

4. Creates a serious risk to the health or safety of the public or a section of the public ${ }^{96}$

The action is not limited to action carried out in the UK and includes action outside the UK. ${ }^{97}$

Regarding neo-Nazi groups, the criteria applied in proscribing them was under promoting or encouraging terrorism as these groups' virulently racist, anti-Semitic and homophobic comments promote a race war, reject democracy and divided society by, '.. implicitly endorsing violence against ethnic minorities and perceived race traitors' ${ }^{98}$ The UK government recognised these groups' online material frequently condoned and glorified those who used extreme violence for political and ideological ends. ${ }^{99}$ The initial tolerance by the UK government of National Action's narrative ceased with the group's promotion and 
encouragement of acts of terrorism following the murder of the MP Jo Cox by Thomas Mair in $2016 .{ }^{100}$

In June 2019 Canada became the second western state to proscribe neo-Nazi groups, Blood \& Honour and Combat 18, as terrorist organisations. Concerned about the violent attacks these groups carried out in North America and Europe since 2012, the Canadian government added them to the list of designate entities. ${ }^{101}$ Although academics and activists for the Canadian government had earlier called to add extreme far-right groups to their list of designated entities, an issue for the Canadian government was having sufficient information on extreme far-right groups that meets the threshold. ${ }^{102}$ The threshold is a statutory one where:

'...the Governor in Council is satisfied that there are reasonable grounds to believe that:

a) the entity has knowingly carried out, attempted to carry out, participated in or facilitated a terrorist activity; or

b) the entity is knowingly acting on behalf of, at the direction of or in association with an entity referred to in paragraph (a), 103

In determining terrorist activity, Canada's legal definition of terrorism is the carrying out an act for a political, religious or ideological purpose, objective or cause, with the intention of intimidating the public or a segment of the public or compelling a person, a government or an international organisation to do or refrain from doing any act be it an act inside or outside Canada. ${ }^{104}$ The act must intentionally:

1. cause the death or serious bodily harm to a person by violence; or

2. endanger a person's life; or

3. cause serious risk to the health and safety of the public or a segment of the public; or

4. cause serious interference with or serious disruption to an essential service, facility or system whether public or private. ${ }^{105}$ 
While close to the UK's definition, the Canadian definition does not include a racial cause.

In January 2020 the German federal government proscribed the extreme farright group Combat18 Deutschland as a terrorist organisation. By 2013 the group had established cells in seven of Germany's 16 states and in 2017 Combat 18 Deutschland members were convicted of illegally importing ammunition to Germany after firearms training in the Czech Republic. ${ }^{106}$ In January 2020 Germany’s Interior Minister, Horst Seehofer, banned Combat 18 Deutschland as a terrorist organisation, referring to the group as, 'Adolf Hitler's task force'. ${ }^{107}$ While there has been a history of violence related to the group, the trigger for the Interior Minister to ban the group was their suspected connection of Combat 18 Deutschland and the murder of leading German politician Walter Lubcke in June 2019. ${ }^{108}$ Key was the intelligence obtained related to the murder by the group forwarded onto the Minister by Germany's domestic security service, Bundesamt fur Verfassungschultz (BfV). The BfV found the group was promoting the ideology of Volksgemainschaft (people's community), a Nazi ideology based on doing without the essential elements of a free democratic basic order and supporting a hierarchy of racial characteristics in society. ${ }^{109}$ Germany does not have a domestic statutory definition of terrorism, but maintains a legal tradition of considering a person a terrorist if they commit or prepare a terrorist attack in Germany. However, agencies involved in countering terrorism like the BfV and the Bundeskriminalamt (Federal German Police Office) have developed internal definitions based on the EU's Framework Decision on combatting terrorism ${ }^{110}$ that covers acts and threats to act with the aim of:

1. seriously intimidating a population; or

2. unduly compelling a Government or international organisation to perform or abstain from performing any act; or 
3. seriously destabilising or destroying the fundamental political, constitutional, economic or social structures of a country or an international organisation. ${ }^{111}$

While there is a disparity regarding a statutory definition of terrorism, at least Germany have recognised the need to start proscribing neo-Nazi groups as terrorist organisations. The importance of this decision is seen in the two recent extreme far-right inspired attacks in Germany, one in Halle on the $9^{\text {th }}$ October 2019 where the gunman broadcast his attack via a camera on his helmet as he shot and killed two people and attempted to enter a synagogue to shoot and kill Jews during their worship. ${ }^{112}$ The second being in Hanau on the $20^{\text {th }}$ February 2020 where after posting neo-Nazi videos and a manifesto on his website, Tobias Rathjen shot and killed ten people at the town's shisha bars. ${ }^{113}$ Other German neo-Nazi groups may be added to the list including Third Way who have recently held demonstrations and parades that emulates Nazi Germany in the 1930's. The BfV have the group under surveillance as it believed Third Way has a clear connection to Nazi ideology. ${ }^{114}$

A variety of US extreme far-right groups have existed for many years, including the American Nazi Party and the KKK. Although their social media accounts have been suspended for promoting white supremacy along with hatred towards non-Aryans/whites, ${ }^{115}$ these two groups websites are available in open source. Both websites are carefully worded to ensure there is no immediate direct encouragement or incitement to lawless action thereby complying with the US' first amendment's protection of freedom of expression. However, formed in 2015, Atomwaffen is a US neo-Nazi group that glorifies and advocates violence and, through the use of terrorism and guerrilla warfare, encourages the overthrow of the US government. ${ }^{116}$ Its website contains graphic videos of their activities, including the burning of the US constitution and flag, promoting a 'race war' and practicing military manoeuvres in rural areas. ${ }^{117}$ Linked to five murders and a bomb plot, including the murder of a 19 year old 
Jewish gay Californian student, Blaze Bernstein in 2017, Atomwaffen attracted international media attention. ${ }^{118}$ At least this neo-Nazi inspired crime has been recognised by US authorities as a hate crime and as such should the defendant and Atomwaffen member, Woodward be convicted of first degree murder it could result in him facing life imprisonment without parole. ${ }^{119}$ In March 2020 five leading Atomwaffen members were arrested and charged with a variety of federal offences, including threatening journalists and illegal possession of firearms and thousands of rounds of ammunition. ${ }^{120}$ Despite all of the arrests and trials related to violent political activity, paradoxically, when you look at the US definition of domestic terrorism, which states it is action that:

1. involves acts dangerous to human life that is a violation of US criminal laws or of any state;

2. appears to be intended to intimidate or coerce a civilian population, or, to influence the policy of a government by intimidation or coercion, or, affect the conduct of a government by mass destruction, assassination or kidnapping; and

3. occurs primarily within the territorial jurisdiction of the US. ${ }^{121}$

it is perplexing as to why the US government has not at least banned Atomwaffen as a terrorist organisation.

Designating groups as terrorist organisations involves a consultation between the Attorney General and Secretary of State of the Treasury and the Secretary of State who can designate foreign entities if they have committed or pose a significant risk of committing acts of terrorism threatening US nationals or national security, foreign policy or economy of the US. ${ }^{122}$ Compared to designating foreign groups, designating domestic groups does not appear to be so straight forward a process as it appears to depends on the weaponry. ${ }^{123}$ In 2015 KKK member, Glendon Scott Crawford was convicted of domestic terrorism when he attempted to acquire a weapon of mass destruction to kill innocent members of the Muslim community. His appeal was dismissed by the US Court of Appeal, second circuit, saying the application of terrorist enhancement (domestic terrorism) was not erroneous, as seen in the definition, he 
attempted to use a 'weapon of mass destruction'. ${ }^{124}$ However if the perpetrator uses a firearm apparently it is not a case of domestic terrorism, it is prosecuted as homicide or a hate crime. This is seen in Roof. ${ }^{125}$ In June 2015 Roof shot and killed nine African Americans attending a bible study group at the Emanuel African Methodist Church in Charleston, South Carolina. At his trial the prosecution submitted evidence of Roof's extreme far-right influence that included his website showing photographs of himself draped in a Confederate flag with guns and symbols of white supremacist movements along with his participation on white supremacist platforms including the Daily Stormer and Stormfront. Posting a manifesto citing his reasons for the attack included his desire to start a race war because of Charleston's high ratio of 'blacks to whites'. Although he used a firearm, it is submitted Roof committed a political attack on the African-American community, ${ }^{126}$ but the FBI classed it as a hate crime, not a political act and subsequently not a terrorist act. ${ }^{127}$ A possible reason why the US does not designate domestic groups is similar to that examined under US hate crime, in that the federal government may not want to be seen as restricting the first amendment's protection of freedom of expression and therefore investigate crimes on a case by case basis as to whether it is an act of domestic terrorism. At the time of writing there have been race riots in the US and 'Black Lives Matters' demonstrations globally following the death of African-American George Floyd by the police in Minneapolis. ${ }^{128}$ Rather than considering to designate extreme far-right groups, ironically, accusing them of starting the riots in the street protests, President Trump is looking to designate the left-wing, anti-fascist group Antifa as a terrorist organization. ${ }^{129}$ In contrast, albeit via four change.org petitions, 390,000 US citizens have signed the petitions for the KKK to be designated as a terrorist organisation, ${ }^{130}$ and, considering the evidence above, perhaps this could also include Atomwaffen and the American Nazi Party. 
The situation in Australia and New Zealand is no different as no extreme far-right groups have been proscribed as terrorist organisations. Australia's Antipodean Resistance is an extreme far-right group promoting the national socialist ideology. Formed in 2016, to date their activity has been limited to placing stickers and posters at various locations such as universities, churches and other public buildings. While innocuous, if the group's influence increases, there is the potential for Antipodean Resistance's activity to develop into violent acts. Their website is clear they are anti-immigration, anti-Islam, anti-Semitic, homophobic, racist, anti-multiculturalism and have no time for liberal democratic principles. ${ }^{131}$ Federal MP, Anne Aly wants Antipodean Resistance proscribed as a terrorist group. She says by focusing solely on Islamist groups Australia is missing a very real threat as Antipodean Resistance is about violence and hatred, not about expressing opinions in a civil debate. Under Australia's legal definition of terrorism, for action to be classed as terrorism, the action taken must be for advancing a political, religious or ideological cause with that action being aimed at influencing or intimidating a government be it Australian or foreign or intimidating the public or a section of the public. ${ }^{132}$ Again, fearful of not being seen to fetter human rights, it might be the Australian government is waiting for the group to commit a violent terrorist act that places people in danger before taking this step. The warning for Australia is there, as the alleged offender of the Christchurch attack is an Australian influenced by extreme farright ideology such as that espoused by Antipodean Resistance. As the group's ideology is about killing people, it only takes one person influenced by the extreme far-right's narrative like that espoused by Antipodean Resistance's for a terrorist attack to succeed. ${ }^{133}$

In designating groups as terrorist organisations, apart from a few nationalist groups like Turkey’s PKK and Columbia’s FARC, New Zealand has mainly designated Islamist groups including IS and Al Qaeda, but, surprisingly, following the Christchurch attack, no extreme far-right groups. The legal criteria in designating groups is when following 
consultation with the Attorney-General and the Minister for Foreign Affairs and Trade, ${ }^{134}$ the Prime Minister may designate an entity as a terrorist organisation if the Prime Minister has good cause to suspect the entity has knowingly carried out or has knowingly participated in the carrying out of one or more terrorist attacks.

Under New Zealand's legal definition a terrorist act is carried out for the purpose of advancing an ideological, political or religious cause in any one or more countries with the intent to induce terror in a civilian population or unduly compel to force a government organisation to do or abstain from doing any act. ${ }^{135}$ The act must:

1. Result in death or serious bodily injury;

2. Serious risk to the health and safety of a population;

3. Destruction or serious damage to property of great value or importance;

4. Major economic loss;

5. Major environmental damage;

6. Serious disruption to an infrastructure facility if likely to endanger human life;

7. Introduction or release of a disease-bearing organism if likely to devastate the national economy of a country. ${ }^{136}$

There are very few extreme far-right groups in New Zealand, but two groups stand out, Dominion Movement and Action Zealandia. Following the Christchurch attack Dominion Movement voluntarily shut down, but evidence reveals there is a direct connection between this group and Action Zealandia, formed in June 2019. ${ }^{137}$ On the group's website, Action Zealandia states as the European identity is under threat in New Zealand the group wants to create a unified voice for, '...concerned NZ Europeans and halt the ongoing replacement', along with creating a community and brotherhood of young New Zealand Europeans. ${ }^{138}$ As seen in Germany, the creation of a people's community is a national socialist ideology. While the group's activity has been placing stickers and posters in public spaces highlighting their ultra-nationalism, ${ }^{139}$ in March 2020 an Action Zealandia member was arrested for disorderly behaviour after racially abusing a Muslim and for non-cooperation 
with the police, with another member being investigated by the police for planning to start a terror cell and purchasing firearms linked to the US group Atomwaffen. ${ }^{140}$ The reason as to why Action Zealandia have not yet been designated as a terrorist group could be due to the legal criteria where evidence is required that a group has knowingly carried out or has knowingly participated in the carrying out of one or more terrorist attacks. Although this is not yet the case with Action Zealandia, the potential is there and maybe rather than wait until this happens, the New Zealand government should follow the example of Canada and the UK and take pre-emptive action against the group.

\section{Examples Where Proscribing Groups as Terrorist Organizations and Hate Crime Legislation Has Assisted Social Media Companies in Banning Far-Right Sites} Terrorist Organisations

In relation to Islamist groups virtually most of the world's states (certainly among the states that have been the focus of this study) have designated them as terrorist organizations, including Al Qaeda and IS, because being international terrorist organizations they pose an international threat. Being universally proscribed/designated as terrorist organizations made easier for social media companies and communications companies to remove these groups' sites. If states adopt the same position in universally proscribing/designating extreme far-right groups as terrorist organizations these companies would not feel the onus on restricting freedom of expression was solely on their shoulders. One problem in proscribing or designating groups extreme far-right groups, is that proscription/designation only applies to the state's jurisdiction carrying out that process. For example, while the group National Action is proscribed as a terrorist organization in the UK, it could exist in any other state where they have not been proscribed/designated. Two approaches can be taken here. One is where there is an obvious international link for example Atomwaffen with Sonnenkreig Division (UK) and Feurekreig Division (Europe) ${ }^{141}$ states can universally proscribe/designate 
them as terrorist organizations. Another example is Combat 18 as this group originated in the UK in the 1992 before spreading to other countries ${ }^{142}$ and, as discussed, in now proscribed in Canada and Germany. The second approach is for states to universally recognize the threat to security groups that have no apparent international threat. This is an approach taken by many states in relation to nationalist groups such as Turkey's PKK who are proscribed in the states studied here but pose no direct that those states' security. Taking this action will make not only make it inordinately easier for companies to remove sites and content, it will also bring investigations into these groups under anti-terrorism laws within those states.

\section{Hate Crime Legislation}

In addition to the extreme far-right, far-right social media and website content can influence individuals to carry out violent attacks. In the UK Darren Osborne was convicted for murder and attempted murder in 2018 after driving a van into Muslim worshippers at the Finsbury Park mosque in London in June 2017. During Osborne's trial evidence revealed he accessed online material posted by both the extreme far-right and the far-right, including the group Britain First, that influenced him to carry out the attack. As a result, the court convicted Osbourne for a terrorist murder, resulting in him receiving a life sentence and having to serve a minimum of 43 years. ${ }^{143}$

Due to its hate crime legislation, there have been some successful suspension of farright social media account holders in the UK. For example, formed as a British ultranationalist political party in 2011, ${ }^{144}$ Britain First is an anti-immigration, anti-Islam and anti-European Union political party, opposed to political or religious doctrines they consider to be destructive in British society. Since its formation Britain First built a large following on both its Facebook and Twitter accounts, with many of its posts being shared on Facebook and tweets retweeted, including in November 2017 when US President Donald Trump retweeted 
three Britain First inflammatory tweets posted by Britain First's deputy leader, Jayda Fransen on the group's Twitter site. ${ }^{145}$ The conviction of the Party's leader, Paul Golding for a number of public order related offences that range from wearing a political uniform ${ }^{146}$ and racial harassment ${ }^{147}$ in Luton in $2016^{148}$ and receiving an 18 week custodial sentence for racial harassment ${ }^{149}$ in Folkestone were the tipping points for Britain First's Twitter being suspended in December 2017 due to breaching Twitter's rules on hate speech. ${ }^{150} \mathrm{~A}$ few months later Facebook banned Britain First for repeatedly posting content designed to incite animosity and hatred against minority groups. ${ }^{151}$

What will have assisted in suspending these UK accounts like Britain First is the UK's legislation on hate crime that will have given them the legitimacy and authority to take this action. While having been critical of US hate crime, in particular the fact the Hate Crimes Act does not include emotional injury and the lack of applying domestic terrorism to investigations and groups, scholars have seen US hate crime and terrorism sharing similar traits as they both act as a message aimed at instilling fear and modifying behaviour. ${ }^{152}$ On this theme Taylor states in the case of hate crime an individual is targeted because of their perceived group membership where the attack not only sends a message to that individual but to the wider group to which that victim belongs. ${ }^{153}$ Others disagree, seeing the two as distant relatives, one because hate crime is more spontaneous compared to the planning involved in acts of terrorism and second that most perpetrators of hate crimes do not seek publicity for their acts whereas terrorists use the publicity to further their goals. ${ }^{154}$ In relation to social media and communications companies, this debate with its inherent ambiguity is not helpful. What is required internationally is uniformly consistent legislation that is clear as to what amounts to hate crime, similar to the legal definitions these states have adopted for terrorism, especially related to international terrorism. For those states that do not have a statutory 
offence of hate crime, seeing how both far-right and extreme far-right ideology is becoming increasingly internationalised, maybe now is the time to introduce hate crime legislation.

Introducing legislation enforcing social media and communications companies to remove illegal content or face legal sanction is not the way forward as such a law has the potential to delete more content than is necessary with the consequence that once more it is these companies that become the guardians of freedom of expression. Another problem for these companies is the live streaming of criminal acts, as seen during the Christchurch attack, as it is difficult to interrupt because live streaming is simultaneously shared and uploaded it is not subject to algorithmic control. ${ }^{155}$ Many of these companies including Microsoft and Google as well as the social media companies are working together to identify and remove extremist content, especially applying the technology to search for hashtags. As hashtags is a type of digital fingerprint it makes it easier for the companies to stop banned content from being repeatedly uploaded on new accounts. ${ }^{156}$ Rather than introduce punitive legislation, introducing universally uniform legislation is preferable in assisting these companies in knowing what to delete and remove from their sites.

\section{Conclusion}

While it may seem obvious as to what content is extremist in nature that could inspire hatred and violence, when it comes to freedom of expression social media and communications companies must follow the law. As discussed, while there is a degree of consistency among states in the wording regarding the right to freedom of expression, there is also discrepancy among those states' jurisdictions on what speech and expression is protected under that right. When this is applied to hate crimes that discrepancy among the states widens further from what activity amounts to a hate crime to it not being a crime but a civil case, to discrepancy in sentencing. As such, this is problematic for social media and communications companies that have to take cognizance of the law in a number of states 
related to freedom of expression and hate crime when deciding what content individuals post is by its nature likely to incite or promote violence or unlawful activity. While these companies have their own policy on hate speech they apply when regulating content posted on their sites, this is a delicate operation as these companies are not the global guardians of freedom of expression in determining what is or is not legitimate political or religious content.

The United Nations General Assembly (UN) under its role in maintaining international peace and security has been called to co-ordinate the global fight against terrorism that resulted in the UN member states adopting the UN Global-Terrorism Strategy in $2006 .{ }^{157}$ As Canada, Germany and the UK are the only states to proscribe extreme far-right groups as terrorist organization it is problematic in relying on the $\mathrm{UN}$ in adopting a universal instrument in relation to the extreme far-right and hate crime. That said the UN general Council could introduce an instrument that encourages its member states to do so. A more pragmatic and immediate approach would be through the G20 states. Recognising that the G20 was formed as a forum for international economic cooperation, ${ }^{158}$ G20 summit meetings is an opportunity for states to discuss how they can minimise the disparity in interpretation of freedom of expression and hate crime with a view to introducing legislation that has a minimum, comparable standard of criminal law elements amounting to hate crime and in proscribing extreme far-right groups. Triggered by the IS inspired attacks in Paris where 109 were killed and Ankara where 109 were killed that year, at the 2015 G20 summit in Turkey the G20 states did produce a statement on the fight against terrorism where they said:

'The fight against terrorism is a major priority for all our countries and we reiterate our resolve to work together to prevent and supress terrorist acts through increased international solidarity and cooperation, in full recognition of the UN's central role...' [my emphasis] ${ }^{159}$ 
Following the Manchester Arena terrorist attack in May 2017, the G7 states released the Taormina statement on the fight against terrorism and violent extremism. ${ }^{160}$ Acknowledging that electronic communications and the internet has proved to be a powerful tool for terrorists and extremists, the G7 called for communications service providers and social media companies to increase their efforts to address terrorist and extremist content. In the statement it requires these companies to act urgently in developing and sharing new technology and tools to improve the automatic detection of content promoting incitement to violence adding that the $G 7$ states are committed to supporting industry efforts. ${ }^{161}$ Both statements mention international cooperation and a commitment to support commucnaitiosn industry efforts, but we are yet to see this commitment in relation to far-right and extreme far-right groups. If the commitment is truly there, then now is the time for both the G20 and G7 to adopt a position of commonality that would include in relation to freedom of expression any comment or speech that promotes or encourages violence is not protected under this right, adding;

1. All hate crime is reported to, recorded and investigated by the police;

2. Hate crime is hatred on the grounds of a person's colour, race, nationality (including citizenship), ethic or national origin, religious belief, absence of religious belief, sexual orientation and disability;

3. Hate crime includes bodily injury and where the victim suffers alarm, harassment and distress (including emotional or psychological harm);

4. Where a recognisable group openly glorifies or promotes violence that will incite, influence or encourage individuals to commit violence on the basis of hate, that group should be proscribed as a terrorist organization.

The most important human right is the right to life and states have a responsibility to protects its citizens' lives and at an international level states working together on hate related crime would help in achieving this. Since the Christchurch attack in March 2019, more lives have been lost as a result of far-right inspired attacks. By states working together on hate crime, especially in relation to dealing with the far-right activity, by having a degree of commonality in its legal provisions it will assist social media and electronic communications 
companies in more readily identifying extremist commentary that is legitimate political and religious commentary to that which is not protected by the right to freedom of expression.

This will enable these companies to feel more able to remove content and suspend accounts without feeling it is they who are impinging on freedom of expression.

\footnotetext{
${ }^{1}$ Ben Strong (2019) 'No Facebook accountability or contrition over terror attack - privacy Commissioner', Radio New Zealand website, March 26, 2019, https://www.rnz.co.nz/news/national/385533/no-facebookaccountability-or-contrition-over-terror-attack-privacy-commissioner (accessed February 6, 2020) 2 Dominic Casciani (2016), 'Social media giants "failing” on extremism - MP's', BBC News website, https://www.bbc.co.uk/news/uk-37180159 (accessed February 6, 2016)

${ }^{3}$ Neil Johnston (2020) 'Far-right terror threat is rising, police chief warns', The Times, February 24, 2020, https://www.thetimes.co.uk/article/far-right-terror-threat-is-rising-police-chief-warns-8nmdsdlvb (accessed February 25, 2020)

${ }^{4}$ Julian Droogan, Lise Waldek and Ryan Blackhall (2018) 'Innovation and terror: an analysis of the use of social media by terror-related groups in the Asia Pacific', Journal of Policing, Intelligence and Counter Terrorism, 13:2, 170-184, pp. 171-172

5 Ibid, p.174

${ }^{6}$ Eitan Azani and Nadine Liv (2018) 'A Comprehensive Doctrine for an Evolving Threat: Countering Terrorist Use of Social Networks', Studies in Conflict and Terrorism, DOI: 10.1080/1057610X.2018.1494874, p.4

${ }^{7}$ Ibid, p.6

8 MacKenzie F. Common (2020) 'Fear the Reaper: how content moderation rules are enforced on social media', International Review of Law, Computers \& Technology, 34:2, 126-152, p127

${ }^{9}$ Ibid

10 lbid, p.132

11 lbid, p.136

12 Ibid, p.134

${ }^{13}$ David Lowe (2018) Terrorism: Law and Policy, London: Routledge, p.98

${ }^{14}$ Berger, J.M. and Morgan, J. (2015) 'The ISIS Twitter Census: Defining and describing the population of ISIS supporters on Twitter', March 20, 2015, Center for Middle East Policy at Brooking, http://webcache.googleusercontent.com/search?q=cache:nUpiATbv50wJ:www.brookings.edu/ $/ \mathrm{media} / \mathrm{resea}$ rch/files/papers/2015/03/isis-twitter-census-bergermorgan/isis twitter census berger morgan.pdf + \&d=1\&hl=en\&ct=clnk\&gl=uk (accessed June 19, 2015)

${ }^{15}$ Katz, R. 11th April 2015 "How Islamic State is still Thriving on Twitter" InSite Blog on Terrorism \& Extremism, http://news.siteintelgroup.com/blog/index.php/entry/377-how-the-islamic-state-is-still-thriving-on-twitter (accessed June 18, 2015)

${ }^{16}$ Klausen, J. (2015) 'Tweeting the Jihad: Social Media Networks of Western Foreign Fighters in Syria and Iraq', Studies in Conflict \& Terrorism 39(1), 1-22, p. 3

${ }^{17}$ Katz, R. 11th April 2015 "How Islamic State is still Thriving on Twitter" InSite Blog on Terrorism \& Extremism, http://news.siteintelgroup.com/blog/index.php/entry/377-how-the-islamic-state-is-still-thriving-on-twitter (accessed June 18, 2015)

${ }^{18}$ Mia Bloom, Hicham Tiflati \& John Morgan (2019) 'Navigating ISIS's Preferred Platform: Telegram', Terrorism and Political Violence, 31:6, 1242-1254, p.1242

19 Ibid, pp.1242-1243

${ }^{20}$ Article 10 (2) ECHR

${ }^{21}$ Section 14 Bill of Rights Act 1990

${ }^{22}$ Article 19 The International Covenant on Civil and Political Rights

23 [1999] EWHC Admin 733
} 
${ }^{24}$ Redmond-Bate $v$ Director of Public Prosecutions [1999] EWHC Admin 733, paragraph 20

${ }^{25}$ Handyside v UK (1976), Application Number 5493/72

${ }^{26}$ Erbaken v Turkey (2006) Application Number 59405/00

27 [1990] 3 SCR 870

${ }^{28} 491$ U.S. 397 (1989)

${ }^{29}$ Near v Minnesota 283 US 697 (1931)

${ }^{30}$ Chaplinsky v New Hampshire 315 US 568 (1942)

${ }^{31}$ Dennis v US 341 US 494 (1951)

32 Brandenburg v Ohio 395 US 444 (1969)

${ }^{33}$ David Lowe (2018) 'Terrorism: Law and Policy', London: Routledge, p.87

${ }^{34}$ Section 319 Canadian Criminal Code

${ }^{35}$ Section 718(2)(a)(i) Canadian Criminal Code

${ }^{36}$ Henry Cockburn (2017) 'Canadian parliament passes anti-Islamophobia motion', March 24, 2017, The

Independent, retrieved from http://www.independent.co.uk/news/world/americas/canada-parliament-anti-

islamophobia-motion-pass-muslim-irqa-khalid-david-anderson-racism-faith-a7647851.html (accessed October $5,2017)$

${ }^{37}$ CBC News (2017) 'House of Commons passes anti-Islamophobia motion', March 23, 2017, CBC News website, http://www.cbc.ca/news/politics/m-103-islamophobia-motion-vote-1.4038016 [accessed October 5, 2017]

38 osce (2018) 'hate Crime Reporting', osce website, https://hatecrime.osce.org/canada (accessed February 7, 2020)

39 [2019] QJ No. 758

40 [1990] 3 S.C.R 870

${ }^{41}[1990]$ S.C.R 697

${ }^{42}[1996]$ S.C.R 458

${ }^{43}$ Section 18 Public Order Act 1986

${ }^{44}$ Section 19 Public Order Act 1986

${ }^{45}$ Section 17 Public Order Act 1986

${ }^{46}$ Section 29A Public Order Act 1986

${ }^{47}$ Section 29AB Public Order Act 1986

${ }^{48}$ Home Office (2019) 'Hate Crime, England and Wales, 2018/19', UK Home Office website,

https://assets.publishing.service.gov.uk/government/uploads/system/uploads/attachment data/file/839172/ hate-crime-1819-hosb2419.pdf (accessed February 8, 2020)

${ }^{49}$ Crown Prosecution Service (2019) 'Hate Crime Report', CPS website, https://www.cps.gov.uk/sites/default/files/documents/publications/CPS-Hate-Crime-Annual-Report-20182019.PDF (accessed February 12, 2020), p.29

${ }^{50}$ Press Association "Internet troll facing jail after violent anti-Semitic threats to Labour MP", The Guardian $27^{\text {th }}$ July 2016 available at $\mathrm{https}$ ://www.theguardian.com/uk-news/2016/jul/27/internet-troll-jail-violentantisemitic-threats-labour-mp-luciana-berger [accessed 21st August 2016]

${ }^{51}$ BBC News (2017) ' MP death threat troll John Nimmo is jailed', BBC News website, February 10, 2017, https://www.bbc.co.uk/news/uk-england-tyne-38934379 (accessed February 2, 2020)

5218 U.S.C. § $245(b)(2)$

5318 U.S. Code $\S 249$

${ }^{54} 18$ U.S. Code $\S 249(1)$

5518 U.S. Code $\S 249(2)$

${ }^{56} 18$ U.S. Code $\S 249(c)(1)$

${ }^{57}$ Case No. $10-\mathrm{cr}-03104$

58404 F. $3 d$ d 320

${ }^{59}$ No. $11-30006$

${ }^{60}$ Colin Dwyer (2017) ' 1 st man Prosecuted for Federal Hate Crime Targeting Transgender Victim gets 49 Years', National Public Radio website, May 16, 2017 https://www.npr.org/sections/thetwo-

way/2017/05/16/528602477/1st-man-prosecuted-for-federal-hate-crime-targeting-transgender-victim-gets$49-y ? t=1581517393233$ (accessed February 6, 2020)

${ }^{61}$ CBC News (2017) 'House of Commons passes anti-Islamophobia motion', March 23, 2017, CBC News website, http://www.cbc.ca/news/politics/m-103-islamophobia-motion-vote-1.4038016([accessed October 5, 2017) 
62 Luke McNamara (2016) 'Explainer: What is section 18C and why do some politicians want it changed?', September 1, 2016, The Conversation, https://theconversation.com/explainer-what-is-section-18c-and-whydo-some-politicians-want-it-changed-64660 (accessed October 5, 2017)

${ }^{63}$ Luke McNamara and Katherine Gelber (2014) 'Explainer: how do Australia's laws on hate speech work in practice?', May 8, 2014, The Conversation, https://theconversation.com/explainer-what-is-section-18c-andwhy-do-some-politicians-want-it-changed-64660 (accessed October 5, 2017)

${ }^{64}$ Kanapathy $v$ In de Braekt (no.4) [2013] FCCA 1368

${ }^{65}$ Ejueyitsi v Commissioner of Police (Western Australia) [2013] FMCA 12

${ }^{66}$ Racial and Religious Tolerance Act 2001, section 7

${ }^{67}$ Racial and Religious Tolerance Act 2001, section 8

${ }^{68}$ Racial and Religious Tolerance Act 2001, section 3

69 Hagar Cohen and Scott Mitchell (2019) 'Hate crime laws rarely used by Australian authorities, police figures reveal', ABC News website, $2^{\text {nd }}$ Many 2019, retrieved from https://www.abc.net.au/news/2019-05-03/hatecrimes-rarely-prosecuted-in-australia/11055938 [accessed 2nd February 2020]

70 James Oaten (2017) 'Far-right nationalists found guilty of inciting serious cotn4empt for Muslims after mock beheading video', ABC News website, $5^{\text {th }}$ September 2017, retrieved from https://www.abc.net.au/news/2017-09-05/three-men-found-guilty-of-inciting-serious-contempt-formuslims/8874804 [accessed 2nd February 2020]

${ }^{71}$ Section 131 Human Rights Act 1993

72 Section 63(1) Human Rights Act 1993

${ }^{73}$ New Zealand Human Rights Commission website, retrieved from https://www.hrc.co.nz/enquiries-andcomplaints/fags/racially-offensive-omments/ [accessed $6^{\text {th }}$ February 2020]

${ }^{74}$ NZ Herald (2017) 'No need for hate crime offences in New Zealand, Justice Minister Amy Adams says', NZ Herald, $15^{\text {th }}$ February 2017, retrieved from

https://www.nzherald.co.nz/nz/news/article.cfm?c id=1\&objectid=11801083 [accessed $2^{\text {nd }}$ February 2020]

75 New Zealand Crime and Victims Survey (2019) 'Topical Report: Highly Victimised People', New Zealand Government, retrieved from https://www.justice.govt.nz/assets/Documents/Publications/HZTYUY-NZCVStopical-report-2018-Highly-Victimised.pdf [accessed 2nd February 2020], pp.6-9

${ }^{76}$ Bruce Edwards (2019) 'Political Roundup: Outlawing hate speech and hate crimes', NZ Herald website, $1^{\text {st }}$ April 2019, retrieved from https://www.nzherald.co.nz/nz/news/article.cfm?c id=1\&objectid=12218243 [accessed $2^{\text {nd }}$ February 2020]

77 William R Huhn (2009) 'Cross Burning as Hate Speech Under the First Amendment to the United States Constitution', Amsterdam Law Forum, Vol 2 No. 1 pp.19-24, p.19

78 Ibid, p.20

${ }^{79} 505$ U.S. 377 (1992)

80538 U.S. 377 (2003)

${ }^{81}$ Section 29 Crime and Disorder Act 1998

82 Section 30 Crime and Disorder Act 1998

${ }^{83}$ Section 31(1) (c) Crime and Disorder Act 1998

${ }^{84}$ Section 5 Public Order Act 1986

85 Section 32(1)(a) Crime and Disorder Act 1998

${ }^{86}$ Section 32(1)(b) Crime and Disorder Act 1998

${ }^{87}$ Erbaken v Turkey (2006) Application number 59405/00

${ }^{88}$ Home Office, 'National Action become first extreme far-right group to be banned in UK', GOV.UK website, December 16, 2016, https://www.gov.uk/government/news/national-action-becomes-first-extreme-rightwing-group-to-be-banned-in-uk (accessed June 28, 2018]

89 'Neo-Nazi Group Sonnenkreig Division Proscribed', Counter-Terrorism Unit website, February 28, 2020 https://www.counterterrorism.police.uk/neo-nazi-group-sonnenkrieg-division-proscribed-counter-terrorismpolice/ (accessed May 21, 2020)

90 Section 3(3) Terrorism Act 2000

${ }^{91}$ Section 3(5) Terrorism Act 2000

92 Section 3(5A) Terrorism Act 2000

93 Section3(5B) Terrorism Act 2000

${ }^{94}$ Section 3(5C) Terrorism Act 2000

${ }^{95}$ Section 1(1) Terrorism Act 2000

${ }^{96}$ Section 1(2) Terrorism Act 2000

97 Section 4(a) Terrorism Act 2000 
98 Home Office, 'Proscribed Terrorist Organisations', Home Office website, December 22, 2017, https://www.gov.uk/government/uploads/system/uploads/attachment data/file/670599/20171222 Proscript ion.pdf (accessed March 28, 2018), 16

${ }_{99}$ Ibid

${ }^{100}$ Home Office, 'Further extreme right-wing groups banned in the UK', GOV.UK website, September 28, 2018, https://www.gov.uk/government/news/further-extreme-right-wing-groups-banned-in-the-uk (accessed March 27, 2018]

${ }^{101}$ Currently Listed Entities, Public Safety Canada website, https://www.publicsafety.gc.ca/cnt/ntnl-scrt/cntrtrrrsm/Istd-ntts/crrnt-Istd-ntts-en.aspx\#59 (accessed May 21, 2020)

102 Jessica Davies, Amarasingam and Leah West (2019) 'Canada is Starting to Outlaw Far-Right groups, and it's About Time', Just Security, July 8, 2019, https://www.justsecurity.org/64813/canada-is-starting-to-outlaw-farright-groups-and-its-about-time/ (accessed may 21, 2020)

103 Section 83.05 Canadian Criminal Code

${ }^{104}$ Section 83.01(b)(A) Canadian Criminal Code

105 Section 83.01(b)(B) Canadian Criminal Code

106 'Germany: Extremism and Counter-Terrorism', Counter-Extremism Project website, April 30,2020, https://www.counterextremism.com/countries/germany (accessed May 21,2020)

107 Deutsche Welle (2020) 'Raids in 6 states as Germany bans “Combat 18"', Deutsche Welle website, January 23, 2020 https://www.dw.com/en/raids-in-6-states-as-germany-bans-combat-18-neo-nazi-group/a-52116504 (accessed May 21, 2020)

108 Ibid

109 'Right-Wing Extremism', Bundesamt fur Verfassungschultz website, https://www.verfassungsschutz.de/en/fields-of-work/right-wing-extremism/what-is-right-wing-extremism (accessed May 21, 2020)

110 'Germany: Extremism and Counter-Terrorism', Counter-Extremism Project website, April 30,2020, https://www.counterextremism.com/countries/germany (accessed May 21,2020)

${ }^{111}$ Article 1 Framework Decision 2002/475/JHA

112 Oliver Holmes and Philip Oltermann (2019) 'Halle synagogue was fortified before anti-Semitic attack', The Guardian, $11^{\text {th }}$ October 2019, retrieved from https://www.theguardian.com/world/2019/oct/11/hallesynagogue-fortified-ahead-antisemitic-attack-germany [accessed 25th February 2020]

113 BBC News (2020) 'Hanau: Germany boosts security amid far-right threat', BBC news website, $21^{\text {st }}$ February 2020, retrieved from https://www.bbc.co.uk/news/world-europe-51586283 [accessed 25th February 2020] 114 Justin Huggler (2019) 'Authorities fear Germany has ore that 12,000 neo-Nazis ready to use violence', The Telegraph, May 3, 2019, https://www.telegraph.co.uk/news/2019/05/03/authorities-fear-germany-has12000-neo-nazis-ready-use-violence/ (accessed June 4, 2020)

${ }^{115}$ Hannah Kuchler (2017), 'Twitter suspends accounts of far-right groups', Financial Times website, $18^{\text {th }}$ December 2017, retrieved from https://www.ft.com/content/5655b042-e411-11e7-97e2-916d4fbac0da (accessed February 7, 2020)

${ }^{116}$ Atomwaffen website, https://atomwaffendivision.org/ (accessed April 3, 2018)

117 Video 'Zealous Operation' from Atomwaffen website, https://www.bitchute.com/video/9NQRhv77fLQi/ (accessed April 3, 2018)

${ }^{118}$ Kyle Swenson, 'Suspects in five killings reportedly linked to macabre neo-Nazi group', The Washington Post, January 29, 2018

${ }^{119}$ Amy Toxin, 'Man Accused of Murdering Gay Student Blaze Bernstein Pleads Not Guilty', Huffington Post, $11^{\text {th }}$ November 11, 2018, https://www.huffingtonpost.com/entry/samuel-woodward-blaze-bernstein-deathnot-guilty us 5be981bde4b0e843889a4ab5 (accessed February 12, 2019]

120 Jason Wilson (2020) 'Sweep of arrests hit US neo-Nazi group connected to five murders', The Guardian, March 6, 2020, https://www.theguardian.com/world/2020/mar/06/neo-nazi-arrests-deals-blow-us-groupatomwaffen-division 9accessed May 22, 2020)

${ }^{121}$ United States Code 18 Part 1 Chapter 113B section 2331 (5)

122 Executive Order 13224

${ }^{123}$ Nathan Carpenter (23018) 'The ad hoc federal crime of terrorism: Why Congress needs to amend the statute to adequately address domestic terrorism', St Johns Law Review, 42, 393-418, p.402

${ }^{124}$ US v Crawford, 16-4261-cr (2 ${ }^{\text {nd }}$ Cir 2017)

125 US v Dylann Storm Roof, 225 F.Supp.3d 419 (2016)

126 Ibid 
${ }^{127}$ Helen Taylor (2019) 'Domestic terrorism and hate crimes: legal definitions and media framing of mass shootings in the United States', Journal of Policing, Intelligence and Counter Terrorism, 14:3, 227-244, p.235

${ }^{128}$ Michael Miller (2020) 'Begging to be heard', The Washington Post, June 4, 2020,

https://www.washingtonpost.com/local/were-begging-for-us-to-be-heard-young-protesters-implore-policeto-acknowledge-them-and-their-cause/2020/06/04/19557452-a507-11ea-b473-04905b1af82b story.html (accessed June 4, 2020)

${ }^{129}$ BBC News (2020) 'Antifa: Trump says group will be designated "terrorist organisation"', BBC News website, May 31, 2020, https://www.bbc.co.uk/news/world-us-canada-52868295 (accessed May 31, 2020)

${ }^{130}$ Ewan Palmer (2020) 'Hundreds of Thousands Sign Petition Urging US Government to Declare KKK a Terrorist group', Newsweek, June 9, 2020, https://www.newsweek.com/kkk-terrorist-group-petition-antifa1509572 (accessed June 9, 2020)

${ }^{131}$ Antipodean Resistance, 'Being White is Not Enough', Antipodean Resistance website, July 19, 2017, http://antipodean-resistance.info/article/2017/07/19/being-white-is-not-enough/ [accessed October 2, 2017]

${ }^{132}$ Section 100.1 Criminal Code 1995 as amended by the Australian Security Legislation Amendment

(Terrorism) Act 2002

133 Ibid

${ }^{134}$ Section 20(4) Terrorism Suppression Act 2002

135 Section 5(2) Terrorism Suppression Act 2002

${ }^{136}$ Section 5(3) Terrorism Suppression Act 2002

137 Marc Daalder (2020) 'Action Zealandia linked to Dominion Movement', Newsroom website, March 13, 2020, https://www.newsroom.co.nz/2020/03/13/1078385/action-zealandia-linked-to-dominion-movement (accessed may 25, 2020)

${ }^{138}$ Action Zealandia Ideals, Action Zealandia website, https://action-zealandia.com/ideals (accessed May 25, 2020)

139 Paul Spoonley, (2020) 'Far-right extremists still threaten New Zealand, a year on from the Christchurch attack', The Conversation, March 10, 2020, https://theconversation.com/far-right-extremists-still-threatennew-zealand-a-year-on-from-the-christchurch-attacks-133050 (accessed may 25, 2020)

${ }^{140}$ Marc Daalder (2020) 'Action Zealandia linked to Dominion Movement', Newsroom website, March 13, 2020, https://www.newsroom.co.nz/2020/03/13/1078385/action-zealandia-linked-to-dominion-movement (accessed may 25, 2020)

${ }^{141}$ Michael Kunzelman and Jari Tanner, (2020) 'Estonian boy, 13, headed neo-Nazi group that plotted synagogue attack in the US', The Times of Israel, April 11, 2020, https://www.timesofisrael.com/estonian-boy13-headed-neo-nazi-group-that-plotted-synagogue-attack-in-us/ (accessed June 4, 2020)

142 BBC News (2020) 'Germany ban Combat 18 as police rid neo-Nazi group', BBC News website, January 23, 2020, https://www.bbc.co.uk/news/world-europe-51219274 (accessed June 4, 2020)

${ }^{143}$ BBC News, (2018) 'Finsbury Park attacker Darren Osborne jailed for minimum of 43 years', February 2, 2018, https://www.bbc.co.uk/news/uk-42920929 (accessed February 2, 2018).

144 Home Office, 'Proscribed Terrorist Organisations', Home Office website, December 22, 2017,

https://www.gov.uk/government/uploads/system/uploads/attachment data/file/670599/20171222 Proscript ion.pdf (accessed March 28, 2018), 19

${ }^{145}$ BBC News, 'Donald trump prepared to apologise for Britain First retweets', January 26, 2018, http://www.bbc.co.uk/news/uk-42829555 (accessed March 27, 2018].

${ }^{146}$ Section 1 Public Order Act 1936

147 Section 5 Public Order Act 1986

148 Paul Wright, 'Britain First leader Paul Golding convicted for wearing "intimidating” fleeces'. International Business Times, August 1, 2016.

${ }^{149}$ Section 32 Crime and Disorder Act 1998

150 BBC News (2017) 'Twitter suspends Britain First leaders', BBC News website, $18^{\text {th }}$ December 2018, retrieved from https://www.bbc.co.uk/news/technology-42402570 [accessed 27th April 2018]

${ }^{151}$ Alex Hern and Kevin Rawlinson (2018) 'Facebook ban Britain First and its leaders', The Guardian, $14^{\text {th }}$ March 2018, retrieved from https://www.theguardian.com/world/2018/mar/14/facebook-bans-britain-first-and-itsleaders [accessed 27th April 2018]

152 Lim H.A. (2009) 'Beyond the immediate victim: Understanding hate crimes as message crimes' in Barbara Perry and Paul Iganski (editors) Hate Crimes, vol 2: The consequences of hate crimes, Westport, CT: Praeger, 107-122

153 Helen Taylor (2019) 'Domestic terrorism and hate crimes: legal definitions and media framing of mass shootings in the United States', Journal of Policing, Intelligence and Counter Terrorism, 14:34, 227-244, p.232 
${ }^{154}$ Kathleen Delougherty, Ryan King and Victor Asal (2012) 'Close cousins or distant relatives? The relationship between terrorism and hate crime', Crime \& Delinquency, 58(5), 663-688, pp. 667-668

${ }^{155}$ MacKenzie F. Common (2020) 'Fear the Reaper: how content moderation rules are enforced on social media', International Review of Law, Computers \& Technology, 34:2, 126-152, p131

${ }^{156} \mathrm{Ibid}$, p.136

157 United Nations - Maintain Peace and Security, UN website, retrieved from https://www.un.org/en/sections/what-we-do/maintain-international-peace-and-security/index.html (accessed February 12, 2020)

158 'What is the G20', G20 website, retrieved from https://g20.org/en/about/Pages/whatis.aspx (accessed February 12, 2020)

${ }^{159}$ G20 Turkey Statement on the Fight Against Terrorism http://www.g20.utoronto.ca/2015/151116terrorism.pdf (accessed February 16, 2020)

160 "G7 Taormina Statement on the Fight against Terrorism and Violent Extremism." Consilium. May 26, 2017, http://www.consilium.europa.eu/en/press/press-releases/2017/05/26/statement-fight-against-terrorism/ (accessed June 20, 2017).

$161 \mathrm{lbid}$, paragraph 5 